\title{
PARTISIPASI MASYARAKAT DALAM PELESTARIAN LINGKUNGAN DI KAWASAN PANTAI PADANG
}

\author{
Gabby Bleszeinsky \\ Jurusan Administrasi Publik, FIS Universitas Negeri Padang \\ gmail: bleszeinsky13@gmail.com \\ Syamsir \\ Jurusan Administrasi Publik, FIS Universitas Negeri Padang \\ Email: syamsirsaili@yahoo.com \\ Jumiati \\ Jurusan Administrasi Publik, FIS Universitas Negeri Padang \\ Email: upikjumati@yahoo.co.id
}

\begin{abstract}
This study aims to determine the Community Participation in Environmental Conservation in the Padang Coast area, to find out the supporting and inhibiting factors in Community Participation in Environmental Conservation in the Padang Beach area, to find out the efforts of the Padang City Culture and Tourism Office in increasing community participation in environmental conservation. This research is a qualitative research with descriptive method. This research was conducted in the Padang Beach Area, Cimpago Beach and Muaro Lasak. Research informants were determined by purposive sampling. Data collected is in the form of secondary data and primary data through interviews, observation and documentation studies. The validity test of the data is done by triangulation and then the data is analyzed by reducing data, displaying data and drawing conclusions during the study. The results of this study indicate that there is still a lack of community participation in the coastal Padang area. Supporting factors found were environmental preservation programs from the Padang city cultural and tourism services and support from the leadership. The inhibiting factors are lack of public awareness, inadequate facilities and infrastructure, lack of awareness from tourists.
\end{abstract}

Keywords: Community participation, environmental conservation

Submitted:13 November $2018 \quad$ Reviewed:22 February $2019 \quad$ Published: 29 April 2019

How to Cite: Gabby Bleszeinsky, Syamsir dan Jumiati. 2019. Partisipasi Masyarakat dalam Pelestarian Lingkungan di Kawasan Pantai Padang. 3(1): pp. 1-13. DOI: https://doi.org/10.24036/jess/vol3-iss1

\section{Pendahuluan}

Permasalahan mengenai partisipasi masyarakat dalam pelestarian lingkungan di kawasan Pantai Padang terlihat dari kurangnya partisipasi masyarakat dalam pelestarian lingkungan. Selain itu, hal ini juga terlihat dari kurangnya sarana prasarana pariwisata di kawasan Pantai Padang, seperti toilet yang hanya tersedia tiga toilet di tiga tempat, sementara para wisatawan tentunya sangat paling membutuhkan toilet umum terutama ruang bilas untuk wisata setelah selesai 
berenang di pantai. Lampu penerangan jalan di sekitar Pantai Padang juga terlihat masih kurang dan akibatnya masih banyak wilayah Pantai Padang yang gelap pada malam hari. Tempat parkir di kawasan Pantai Padang juga kurang tertata dengan baik sehingga kendaraan parkir sembarangan saja di tepi jalan meskipun ada tanda dilarang parkir. Padahal sebenarnya tempat parkir sudah disediakan di dekat jembatan Purus; dan yang paling parahnya lagi adalah bahwa para petugas parkir memperbolehkan kendaraan parkir sembarangan dan akibatnya mengganggu pengguna jalan lainya serta menyebabkan terjadinya macet di Pantai Purus.

Selain itu juga masih terlihat dan terasa kurangnya fasilitas kebersihan di Padang, terutama di bagian Pantai Purus, seperti bak penampungan sampah sehingga pantai menjadi kotor dan banyak sampah yang dibuang sembarangan, termasuk di bagian pantai Muaro Lasak (masih dalam kawasan Pantai Padang). Banyaknya sampah yang berserakan ini juga berkaitan dengan keberadaan pedagang di sekitar pantai ini. Walaupun telah disediakan kios untuk pedagang di sekitar kawasan Danau Cimpago, Pantai Padang, namun masih ada juga Pedagang Kaki Lima (PKL) yang berjualan di pinggir pantai sehingga Pantai Purus Kota Padang menjadi kotor dan banyak sampah. Menurut Perda 21 tahun 2012 tentang Pengelolaan Sampah, untuk mewujudkan lingkungan yang sehat dan bersih dari sampah, perlu dilakukan pengelolaan sampah secara komprehensif dan terpadu dari hulu ke hilir.

Apabila kondisi Pantai Padang seperti digambarkan di atas tidak ditanggulangi maka akan dapat menyebabkan turunnya minat masyarakat dan wisatawan berkunjung ke lokasi tersebut. Dalam upaya menciptakan pariwisata pantai yang baik bersih dan sehat dalam pelaksanaanya tidak hanya dilakukan oleh pemerintah saja tetapi juga melibatkan partisipasi masyarakat. Dengan potensi yang demikian besar, agar pengembangan pariwisata, termasuk wisata bahari, memberikan manfaat bagi pembangunan maka dalam pelaksanaannya dibutuhkan strategi yang terencana dan sistematis bagi masyarakat lokal. Keterlibatan atau partisipasi masyarakat lokal menjadi penting termasuk dalam kaitannya dengan upaya keberlanjutan pariwisata itu sendiri dan terhadap lingkungan, maupun manfaatnya bagi kesejahteraan masyarakat.

Hal ini penting dilakukan agar pengembangan pariwisata tidak hanya demi meningkatkan penerimaan daerah tetapi juga betul-betul memberikan manfaat bagi masyarakat terutama yang berada di daerah obyek wisata yang bersangkutan. Bila daerah obyek wisata itu adalah juga tempat masyarakat beraktivitas, maka pengembangan wisatanya juga memberikan manfaat bagi masyarakat. Jangan sampai masyarakat yang secara umum masih mengalami kemiskinan dan ketertinggalan justru tersingkir karena berkembangnya pariwisata.

Dalam Pelestarian lingkungan pantai juga diperlukan partisipasi masyarakat terutama mereka yang tinggal di sekitar Pantai Padang. Rahardjo (dalam A. Oktami Dewi, 2013) mengemukakan bahwa partisipasi diartikan sebagai upaya peran serta masyarakat dalam suatu kegiatan baik dalam bentuk pernyataan maupun kegiatan. Lebih lanjut dijelaskan partisipasi merupakan keikutsertaan masyarakat dalam program-program pembangunan. Pada dasarnya partisipasi dibedakan menjadi dua, yaitu partisipasi yang bersifat swakarsa dan 
partisipasi yang bersifat dimobilisasikan. Partisipasi swakarsa mengandung arti bahwa keikutsertaan dan peran sertanya atas dasar kesadaran dan kemauan sendiri, sementara partisipasi yang dimobilisasikan memiliki arti keikutsertaan dan berperan serta atas dasar pengaruh orang lain.

Menurut UU No 32 tahun 2009 tentang Perlindungan dan Pengelolaan Lingkungan Hidup, perlindungan dan pengelolaan lingkungan hidup adalah upaya sistematis dan terpadu yang dilakukan untuk melestarikan fungsi lingkungan hidup dan mencegah terjadinya pencemaran dan/atau kerusakan lingkungan hidup yang meliputi perencanaan, pemanfaatan, pengendalian, pemeliharaan, pengawasan, dan penegakan hukum. Upaya pelestarian lingkungan hidup ini tidak akan bisa dilakukan hanya oleh pihak pemerintah saja. Upaya pelestarian lingkungan hidup juga memerlukan peran serta (partisipasi) semua elemen bangsa, termasuk dan terutama partisipasi masyarakat.

Berdasarkan penjelasan dan uraian di atas maka rumusan masalah yang dikemukakan dalam penelitian ini adalah: 1) bagaimanakah bentuk partisipasi masyarakat dalam pelestarian lingkungan di kawasan Pantai Padang?, 2) faktorfaktor apakah yang menjadi pendukung dan penghambat partisipasi masyarakat dalam pelestarian lingkungan di Pantai Padang?, dan 3) apa upaya yang dilakukan Dinas Pariwisata dan Kebudayaan Kota Padang untuk meningkatkan partisipasi masyarakat dalam pelestarian lingkungan di Pantai Padang?.

\section{Tinjauan Kepustakaan}

\section{Partisipasi}

Rahardjo (dalam A. Oktami Dewi, 2013) mengemukakan bahwa partisipasi dapat diartikan sebagai upaya peran serta masyarakat dalam suatu kegiatan baik dalam bentuk pernyataan maupun kegiatan. Lebih lanjut dijelaskan partisipasi merupakan keikutsertaan masyarakat dalam program-program pembangunan. Pada dasarnya partisipasi dibedakan menjadi dua, yaitu partisipasi yang bersifat swakarsa dan partisipasi yang bersifat simobilisasikan. Partisipasi swakarsa mengandung arti bahwa keikutsertaan dan peran sertanya atas dasar kesadaran dan kemauan sendiri, sementara partisipasi yang dimobilisasikan memiliki arti keikutsertaan dan berperan serta atas dasar pengaruh orang lain. ikatan yang membuat suatu kesatuan manusia menjadi suatu masyarakat adalah pola tingkah laku yang khas mengenai semua faktor kehidupan dalam batas kesatuan. Lagipula, pola itu harus besifat mantap dan kontinu. Dengan kata lain, pola khas itu harus sudah menjadi adat istiadat yang khas. Warga suatu masyarakat harus juga mempunyai ciri lain, yaitu suatu rasa identitas bahwa mereka memang merupakan suatu kesatuan khusus yang berbeda dari kesatuan-kesatuan manusia lainnya.

Partisipasi adalah keikutsertaan, perhatian, dan sumbangan yang diberikan oleh kelompok yang berpatisipasi, dalam hal ini adalah masyarakat (Pasaribu dan Simanjuntak, 1992). Untuk menumbuhkan dan menggerakkan semangat partisispasi, diperlukan prasyarat yang dapat membangkitkan tenaga sosial dalam masyarakat. Pasaribu dan Simanjuntak mengemukakan bahwa prasyarat tersebut adalah sebagai berikut: 
1) Rasa senasib, sepenanggungan, ketergantungan dan ketertibaan; jika dalam suatu masyarakat terdapat perasaan ini, maka dalam masyarakat ikut dapat diharapkan timbul partisipasi yang tinggi;

2) Keterikatan tujuan hidup; keterikatan rasa saja tidak membawa kekuatan untuk berpartisipasi. Bila tujuan jelas maka ketepatan hati, tahan uji dan kemauan keras akan timbul dalam mencapai tujuan;

3) Kemahiran menyesuaikan; kemahiran menyesuaikan diri dalam keadaan sangat penting untuk menimbulkan partisipasi;

4) Adanya prakarsawan; adanya orang yang memprakarsai perubahan, merupakan memprasyarat lahirnya partisipasi; dan

5) Iklim partisipasi; partisipasi yang bagaimanapun tidak akan lahir tanpa lebih dahulu menciptakan iklim, tetapi bila iklimnya sudah ada, maka sangat mudah partisipasi tumbuh.

Partisipasi sebenarnya sangat beranekaragam, bukan sekedar perkumpulan masyarakat di satu tempat tertentu untuk mendengarkan penjelasan mengenaiyang dilarang dari atas. Nelson (dalam Melis, 2016) menyatakan bahwa secara umum corak partisipasi dapat dibedakan menjadi partisipasi dalam pemilihan (electoral participation), partisipasi kelompok (group participation), kontak antara warga Negara dan pemerintah (citizen government contacting), dan partisipasi warga Negara secara langsung di lingkungan pemerintah. Sedangkan Mikkelsen (dalam Isbandi Rukminto Adi, 2012) melihat bahwa konsep partisipasi telah menjadi bagian dari debat yang berkepanjangan antara lain terkait landasan teoritis, dan dengan kemugkinan diterapkannya dalam kaitan dengan berbagai program pembangunan yang dilaksanakan oleh berbagai lembaga Pemerintah dan lembaga non pemerintah. Beberapa pengertian tentang partisipasi menurut Mikkelsen kadangkala lebih merupakan kata-kata populer yang sering digunakan dan belum bermakna sebagai partisipasi yang sesungguhnya. Partisipasi sesungguhnya menurut Mikkelsen berasal dari masyarakat dan dikelola oleh masyarakat itu sendiri. Ia adalah tujuan dalam proses demokrasi. Dengan demikian partisipasi masyarakat secara sederhana dapat diartikan sebagai keikutsertaaan masyarakat pada suatu kegiatan atau program secara keseluruhan, yakni dari awal kegiatan atau pada saat program tersebut akan direncanakan, sedang direncanakan, dan ketika dilaksanakan hingga hasilnya telah diperoleh.

Sementara itu, menurut Sastropoetro (1998) proses peran serta atau partisipasi menggambarkan keterlibatan personal dalam bentuk:

1) Proses pengambilan keputusan; mencakup proses pengambilan keputusan yaitu pengambilan bagian dengan menyalurkan ide, materi, tenaga, maupun keterampilan untuk mengambil suatu keputusan yang dibuat baik dalam sebuah organisasi maupun kehidupan bermasyarakat.

2) Menentukan kebutuhan yang diinginkan; mencakup kebutuhan yang diinginkan dalam partisipasi untuk melestarikan lingkungan dengan menyediakan kebutuhan sarana dan prasarana.

3) Menujukan dan mewujudkan tujuan dan prioritas yang ingin dicapai; Untuk menunjukan dan mewujudkan tujuan dan prioritas yang ingin dicapai perlu adanya evaluasi. Evaluasi ini berkaitan dengan pelaksanaan program secara 
menyeluruh dan partisipasi ini bertujuan untuk mengetahui ketercapaian program yang telah direncanakan.

Menurut Slamet (dalam Wira Pranata, 2014) ada beberapa faktor pendukung dan penghambat partisipasi masyarakat. Partisipasi masyarakat dalam proses pembangunan akan terwujud sebagai suatu kegiatan nyata apabila terpenuhi tiga faktor utama yang mendukungnya, yaitu:

a. kemauan

b. kemampuan

c. kesempatan bagi masyarakat untuk berpartisipasi

Ketiga faktor tersebut akan dipengaruhi oleh berbagai faktor di seputar kehidupan manusia yang saling berinteraksi satu dengan yang lainnya, seperti psikologis individu, harapan, motif, reward, pendidikan, adanya informasi, keterampilan, teknologi, kelembagaan yang mendukung, struktural dan stratifikasi sosial, budaya lokal serta peraturan dan pelayanan pemerintah. Menurut Oppenheim (dalam Wira Prananta, 2014) ada unsur yang mendukung untuk berperilaku tertentu pada diri seseorang (person inner determinants) dan terdapat iklan atau lingkungan (environmental factors) yang memungkinkan terjadinya perilaku tersebut.

Menurut Sahidu (dalam Wira Prananta, 2014) faktor-faktor yang mampengaruhi tingkat kemauan masyarakat untuk berpartisipasi adalah motif, harapan, needs, rewards dan penguasaan informasi. Faktor yang memberikan kesempatan masyarakat untuk berpartisipasi adalah pengaturan dan pelayanan, kelembagaan, struktur dan stratifikasi sosial, budaya lokal, kepemimpinan, sarana dan prasarana. Sedangkan faktor yang mendorong adalah pendidikan, modal dan pengalaman yang dimiliki.

Sementara itu Marzali (dalam Wira Prananta, 2014) mengemukakan bahwa ada tiga prinsip dasar dalam menumbuhkan partisipasi masyarakat desa agar ikut serta dalam pembangunan. Hal itu dapat dilakukan dengan cara:

1) Learning process (learning by doing); Proses kegiatan dengan melakukan aktivitas proyek dan sekaligus mengamati, menganalisa kebutuhan dan keinginan masyarakat.

2) Institutional development; Melakukan kegiatan melalui pengembangan pranata sosial yang sudah ada dalam masyarakat. Karena institusi atau pranata sosial masyarakat merupakan daya tampung dan daya dukung sosial.

3) Participatory; Cara ini merupakan suatu pendekatan yang umum dilakukan untuk dapat menggali need yang ada dalam masyarakat

Selain itu ada beberapa faktor yang dapat memengaruhi partisipasi masyarakat dalam suatu program. Sifat faktor-faktor tersebut dapat mendukung suatu keberhasilan program namun ada juga yang sifatnya dapat menghambat keberhasilan program. Misalnya saja faktor usia, terbatasnya harta benda, pendidikan, pekerjaan dan penghasilan. Angell (dalam Wira Prananta, 2014) mengatakan partisipasi yang tumbuh dalam masyarakat dipengaruhi oleh banyak faktor. Faktor-faktor yang mempengaruhi kecenderungan seseorang dalam berpartisipasi, yaitu: 
1) Pola Pikir Masyarakat; pola pikir seseorang sangatlah berperan penting dalam sebuah masyarakat. Pola pikir antara masyarakat dengan pemerintah tentunya berbeda.

2) Usia; faktor usia merupakan faktor yang memengaruhi sikap seseorang terhadap kegiatan-kegiatan kemasyarakatan yang ada. Mereka dari kelompok usia menengah ke atas dengan keterikatan moral kepada nilai dan norma masyarakat yang lebih mantap, cenderung lebih banyak yang berpartisipasi daripada mereka yang dari kelompok usia lainnya.

3) Pendidikan; dikatakan sebagai salah satu syarat mutlak untuk berpartisipasi, karena pendidikan dianggap dapat memengaruhi sikap hidup seseorang terhadap lingkungannya, suatu sikap yang diperlukan bagi peningkatan kesejahteraan seluruh masyarakat.

4) Pekerjaan dan penghasilan; hal ini tidak dapat dipisahkan satu sama lain karena pekerjaan seseorang akan menentukan berapa penghasilan yang akan diperolehnya. Pekerjaan dan penghasilan yang baik dan mencukupi kebutuhan sehari-hari dapat mendorong seseorang untuk berpartisipasi dalam kegiatan-kegiatan masyarakat. Pengertiannya bahwa untuk berpartisipasi dalam suatu kegiatan, harus didukung oleh suasana yang mapan perekonomian.

\section{Pelestarian Lingkungan}

Lingkungan hidup adalah suatu benda, daya dan kondisi yang terdapat dalam suatu tempat atau ruang tempat manusia dan mahluk hidup berada dan dapat mempengaruhi hidupnya. Lingkungan hidup sering disebut sebagai lingkungan, adalah istilah yang dapat mencakup segala mahluk hidup dan tak hidup di alam yang ada di bumi atau bagian dari bumi yang berfungsi secara alami tanpa campur tangan manusia yang berlebihan. Dalam Undang-Undang Nomor 23 Tahun 1997 tentang Pengelolaan Lingkungan Hidup menyebutkan pengertian lingkungan adalah kesatuan ruang dengan semua benda, daya, keadaan dan makhluk hidup termasuk manusia dan prilakunya yang mempengaruhi kelangsungan perikehidupan dan kesejahteraan manusia serta makhluk hidup lain (Pasal 1 ayat 1). Sementara menurut Supardi (2003), lingkungan atau sering juga disebut lingkungan hidup adalah jumlah semua benda hidup dan benda mati serta seluruh kondisi yang ada di dalam ruang yang kita tempati.

Bagi manusia, daya dukung lingkungan sangat penting bagi kehidupan. Daya dukung yang dimaksud adalah seberapa banyak jumlah unsur, baik biotik maupun abiotik yang dapat dimanfaatkan dan menjamin kehidupan sejumlah penduduk yang mendiami suatu lingkungan. Pada suatu saat, lingkungan tidak dapat lagi memenuhi syarat kehidupan penghuninya karena daya dukung mulai berkurang atau akibat menurunnya kualitas lingkungan akibat ulah manusia atau adanya pencemaran. Menurut Supardi (2003), upaya menghalangi atau mengurangi terjadinya penurunan kualitas lingkungan, maka perlu adanya suatu pedoman untuk mempertahankan kelestarian lingkungan yaitu:

1) Manusia hendaknya selalu memelihara dan memperbaiki lingkungan untuk generasi mendatang. 
2) Dalam pemanfaatan sumber-sumber daya yang non renewable (yang tidak dapat diganti) perencanaan dan pengelolaannya harus efektif dan efisien.

3) Pembangunan ekonomi dan sosial hendaknya ditujukan selain untuk kesejahteraan umat juga untuk memperbaiki kualitas lingkungan.

4) Dalam mengadakan kebijaksanaan lingkungan, hendaknya diarahkan kepada peningkatan potensi pembangunan bukan sebatas untuk masa kini tetapi juga untuk masa yang akan datang.

5) Ilmu dan teknologi yang diterapkan untuk pemecahan masalah lingkungan harus ditujukan demi kegunaan seluruh umat manusia.

6) Perlu adanya pendidikan, pelatihan maupun pengembangan secara ilmiah tentang pengelolaan lingkungan sehingga semua problem-problem lingkungan dapat ditanggulangi.

7) Ada kerjasama yang baik dari semua pihak dalam rangka mempertahankan kelestarian dan mencegah terjadinya kerusakan atau kemusnahan.

\section{Partisipasi Masyarakat dalam Pelestarian Lingkungan Berdasarkan Undang-Undang Lingkungan Hidup}

Pada hakikatnya, keseriusan dalam memahami permasalahan lingkungan menuntut adanya komitmen yang kuat dari berbagai pihak, termasuk masyarakat dalam mematuhi dan mentaati berbagai instrumen kebijakan dan ketentuan formal. Penyelenggara negara dalam hal ini, mempunyai integritas dan kredibilitas yang menjadi dasar tindakan dalam pengelolaan lingkungan hidup untuk tercapainya tujuan dan sasaran pengelolaan lingkungan. Sementara, keterlibatan (peran serta) masyarakat justru menjadi penting untuk meminimalisir kemungkinan terjadinya permasalahan lingkungan. Peran dan partisipasi masyarakat dalam berbagai sektor publik telah banyak diakomodir dalam berbagai kebijakan publik di negeri ini. Semenjak adanya pengakuan partisipasi masyarakat dalam perumusan kebijakan publik diakomodir dalam Pasal 53 UU No. 10/2004 tentang Penyusunan Peraturan Perundang-Undangan, maka banyak Undang-Undang yang lahir setelah itu yang memuat klausul khusus yang mengatur ihwal partisipasi masyarakat, termasuk UU No. 32/2009 tentang Perlindungan dan Pengelolaan Lingkungan Hidup (UUPPLH).

Secara umum bentuk partisipasi masyarakat dapat dibedakan menjadi empat macam, yaitu partisipasi dalam:

1) Tahap pembuatan keputusan. Dalam hal ini, sejak awal masyarakat telah dilibatkan dalam proses perencanaan dan perancangan kegiatan serta dalam pengambilan keputusan atas rencana yang akan dilaksanakan.

2) tahap implementasi. Keterlibatan masyarakat juga diupayakan pada tahap pelaksanaan kegiatan. Dengan demikian, masyarakat dapat mengontrol bagaimana kegiatan dilaksanakan di lapangan.

3) Tahap evaluasi. Evaluasi secara periodik umumnya dilaksanakan pada tahap pelaksanaan dan pada akhir pelaksanaan kegiatan.

4) Partisipasi untuk memperoleh manfaat suatu kegiatan. 


\section{Metode Penelitian}

Penelitian ini adalah penelitian kualitatif dengan menggunakan metode deskriptif. Dikatakan demikian, karena penelitian berusaha mendeskripsikan gejala, kejadian, peristiwa yang terjadi di lapangan apa adanya, tanpa melakukan penambahan atau intervensi terhadap sasaran penelitian. Proses penelitian kualitatif ini melibatkan upaya-upaya penting, seperti mengajukan pertanyaan-pertanyaan dan prosedur mengumpulkan data yang spesifik dari para partisipan, menganalisis data secara induktif mulai dari tema-tema yang khusus ke tema-tema umum, dan menafsirkan makna data. Laporan akhir untuk penelitian ini memiliki struktur atau kerangka yang fleksibel. Penelitian ini dimaksudkan untuk mendeskripsikan partisipasi masyarakat dalam pelestarian lingkungan di kawasan Pantai Padang.

Penelitian ini dilakukan di kawasan Muaro Lasak-Pantai Cimpago Kota Padang, Dinas Kebudayaan dan Pariwisata Kota Padang. Teknik penentuan informan dilakukan secara purposive dengan pertimbangan tertentu, yaitu terhadap orang-orang yang dapat memberikan data secara maksimal. Informan sebanyak 14 orang yang terdiri dari Kepala Dinas Kebudayaan dan Pariwisata Kota Padang, Kasubag Umum Dinas Kebudayaan dan Pariwisata Kota Padang, masyarakat di sekitar Pantai Padang, pedagang di sekitar Pantai Padang, dan para wisatawan. Adapun jenis dan sumber data yang terdapat dalam penelitian ini adalah data primer dalam penelitian ini diperoleh melalui wawancara dan observasi yang berkaitan dengan partisipasi masyarakat dalam pelestarian lingkungan di kawasan Pantai Padang. Data sekunder diperoleh melalui dokumendokumen seperti profil Dinas Kebudayaan dan Pariwisata Kota Padang (sejarah, visi dan misi, tugas pokok dan fungsi, struktur organisasi). Teknik pengumpulan data yang digunakan adalah wawancara, observasi dan studi dokumentasi. Sementara analisis data dalam penelitian ini menggunakan teknik analisis model interaktif.

\section{Hasil Penelitian dan Pembahasan}

\section{Partisipasi masyarakat dalam Pelestarian Lingkungan di kawasan Pantai Padang}

Menurut Sastropoetro (1998) partisispasi berarti melakukan keterlibatan terhadap suatu masalah yang memerlukan peran serta dari berbagai kalangan di sekelilingnya untuk dapat mencapai tujuan. Proses peran serta atau partisipasi menggambarkan keterlibatan personal dalam bentuk:

1. Proses Pengambilan Keputusan

Proses pengambilan keputusan mencakup pengambilan bagian dengan menyalurkan ide, materi, tenaga, maupun keterampilan untuk mengambil suatu keputusan yang dibuat baik dalam sebuah organisasi maupun kehidupan bermasyarakat. Kawasan wisata Pantai Padang memiliki aktifitas menikmati keindahan laut dan kuliner serta arena bermain. Pantai ini dikelola oleh Dinas Pariwisata Kota Padang. Pada saat ini pemerintah sudah membuat suatu program untuk melestarikan lingkungan dan membuat kawasan pantai padang menjadi tempat wisata yang indah akan kebersihan, kenyamanan, dan keamanan. Salah 
satu pengambilan keputusan yang dibuat oleh pemerintah adalah suatu program yang mana dalam program tersebut pemerintah menyediakan bus pariwisata pada hari Sabtu dan Minggu (weekend). Bus ini dibayar dengan pengumpulan sampah plastik yang berserakan oleh masyarakat (penumpang) di kawasan Pantai Padang dan pemerintah juga menghimbau masyarakat untuk melakukan gotong royong (goro) setiap hari Sabtu pagi. Disamping itu, pemerintah juga menyebarkan pamflet ke masyarakat untuk menjaga kelestarian lingkungan.

Namun demikian, program yang direncanakan pemerintah belum sepenuhnya telaksana dengan baik, karena program yang dibuat pemerintah tidak didukung dengan baik dan serius oleh masyarakat dan wisatawan. Hal ini dikarenakan kurangnya partisipasi masyarakat untuk melestarikan lingkungan di kawasan Pantai Padang dan dengan itu mengakibatkan masih adanya sampah yang berserakan di kawasan Pantai Padang. Tentu dalam hal ini pelestarian lingkungan di kawasan Pantai Padang menjadi tidak berjalan dengan baik. Oleh karena itu partisipasi masyrakat sangat perlu ditingkatkan dan serta pemerintah harus lebih membimbing dan bekerjasama dengan masyarakat agar program yang dijalankan oleh pemerintah berjalan sesuai yang diharapkan.

\section{Menentukan Kebutuhan yang Diinginkan}

Kegiatan penentuan kebutuhan ini mencakup kebutuhan dalam partisipasi untuk melestarikan lingkungan dengan menyediakan kebutuhan sarana dan prasarana. Kawasan Pantai Padang saat ini memiliki berbagai sarana dan prasarana (fasilitas) berupa gazebo, trotoar, tempat parkir, tempat berdagang, tempat bermain anak, toilet, mushalla. Sarana penunjang lainnya yang tersedia berupa restoran, hotel, pujasera yang berada di sisi jalan sekitar pantai. Pantai Padang memiliki nama kecil di sepanjang pantai tersebut, seperti Pantai Hang Tuah, Pantai Purus, Pantai Cimpago, dan Pantai Muaro Lasak. Pantai Cimpago terletak di Jalan Samudera yang bersebelahan dengan Pantai Muaro Lasak.

Permasalahan yang menyangkut sarana dan prasarana di kawasan Pantai Padang yaitu masih kurangnya sarana dan prasarana terutama tong sampah di sekitar Pantai Padang. Tong sampah di Pantai Padang seringkali tampak penuh dan membuat sampah-sampah yang ada di sekitar objek wisata Pantai Padang menjadi tidak teratasi pengelolaannya. Disamping itu toilet terlihat kurang memadai di Pantai Muaro Lasak dan pengelolaan parkir yang terlihat asal-asalan. Hal ini juga termasuk dalam konteks pelestarian lingkungan, karena parkir yang asal-asalan membuat lingkungan menjadi terkesan semerawut dan tidak enak dipandang mata, serta terkesan kumuh. Padahal untuk menjadikan kawasan wisata pantai yang bersih dan lestari tentu dapat dilihat dari kebersihan, kenyamanan, keamanan, dan keindahan.

\section{Menujukan dan Mewujudkan Tujuan dan Prioritas yang Ingin Dicapai}

Untuk menujukan dan mewujudkan tujuan dan prioritas yang ingin dicapai perlu adanya evaluasi. Evaluasi ini berkaitan dengan pelaksanaan program secara menyeluruh dan partisipasi ini bertujuan untuk mengetahui ketercapaian program yang telah direncanakan. Namun dalam kenyataannya program yang telah 
dilaksanakan oleh pihak terkait tidak jelas pengevaluasiannya. Selain itu keterlibatan masyarakat dalam evaluasi penerapan program pemerintah di kawasan Pantai Padang juga tidak begitu terlihat dengan jelas.

\section{Faktor-faktor Pendukung dan Penghambat Partisipasi dalam Pelestarian Lingkungan}

Ada beberapa faktor yang dapat mendukung partisipasi masyarakat dalam pelestarian lingkungan (Marzali dalam Wira Prananta, 2014), antara lain:

1. Learning process (learning by doing); Hal ini mencakup proses kegiatan dengan melakukan aktivitas proyek dan sekaligus mengamati, menganalisa kebutuhan dan keinginan masyarakat. Pemerintah dalam hal ini memberikan suatu pembelajaran bagi masyarakat maupun wisatawan. Dalam kasus pelestarian lingkungan di Pantai Padang, Pemerintah Kota Padang melalui Dinas Kebudayaan dan Pariwisata secara umum telah memberikan perhatian cukup serius terhadap pelestarian lingkungan di kawasan Pantai Padang dalam rangka mewujudkan kawasan wisata pantai yang indah.

2. Institusional development; yaitu melakukan kegiatan melalui pengembangan pranata sosial yang sudah ada dalam masyarakat. Karena institusi atau pranata sosial masyarakat merupakan daya tampung dan daya dukung sosial. Dalam hal ini Pemerintah Kota Padang selalu memantau masyarakat agar tidak merusak lingkungan dan pemerintah menugaskan SATPOL PP untuk menindak masyarakat yang merusak lingkungan pantai.

3. Participatory; Cara ini merupakan suatu pendekatan yang umum dilakukan untuk dapat menggali kebutuhan yang ada dalam masyarakat. Pemerintah Kota Padang dalam hal ini sudah berusaha untuk menghimbau masyarakat dan wisatawan untuk ikut berpartisipasi dalam melestarikan lingkungan Pantai Padang melalui program-program yang telah dijalankan oleh pemerintah.

Selain faktor-faktor pendukung, menurut Marzali (dalam Wira Prananta, 2014), ada pula beberapa faktor yang dapat meghambat partisipasi masyarakat dalam pelestarian lingkungan. Hal ini juga terjadi dalam pelestarian lingkungan di kawasan Pantai Padang, antara lain:

1. Pola Pikir Masyarakat; Masyarakat masih bergantung terhadap pemerintah dalam mewujudkan partisipasi atau keterlibatan masyarakat secara aktif dan masyarakat tidak memiliki inisiatif untuk melakukan pelestarian lingkungan di kawasan Pantai Padang.

2. Pengetahuan dan keahlian; Dasar pengetahuan yang dimiliki akan mempengaruhi seluruh lingkungan serta membuat masyarakat memahami atau tidak terhadap tahap-tahap dan bentuk dari partisipasi yang ada, maka dari itu pentingnya tingkat pengetahuan dan keahlian masyarakat untuk dapat berpartisipasi di kawasan Pantai Padang.

3. Pekerjaan Masyarakat; Pekerjaan masyarakat juga bisa menjadi faktor penghambat dalam berpartisipasi karena pekerjaan tertentu akan dapat meluangkan waktunya untuk berpartisipasi pada suatu proyek tertentu. 
Seringkali pekerjaan dijadikan sebagai hambatan bagi masyarakat untuk berpartisipasi dalam pelestarian lingkungan di kawasan Pantai Padang.

4. Tingkat pendidikan dan buta huruf; Faktor ini sangat berpengaruh bagi keinginan dan kemampuan masyarakat untuk berpartisipasi serta memahami dan melaksanakan tingkatan dan bentuk partisipasi yang ada. Jika masyarakat itu buta huruf maka hal itu sangat berpengaruh dalam berpartisipasi. Dalam kasus pelestarian lingkungan di kawasan Pantai Padang, faktor tingkat pendidikan masyarakat yang cenderung rendah juga ikut mempengaruhi upaya pelestarian lingkungan.

\section{Upaya Dinas Kebudayaan dan Pariwisata Kota Padang dalam Peningkatan Partisipasi Masyarakat dalam Pelestarian Lingkungan}

Secara ringkas dapat dikemukakan bahwa upaya yang dilakukan Dinas Kebudayaan dan Pariwisata Kota Padang dalam pelestarian lingkungan di kawasan Pantai Padang antara lain telah dilakukan dengan cara memberikan pembelajaran terkait pelestarian lingkungan di kawasan Pantai Padang. Untuk menumbuhkan sebuah partisipasi dan keikutsertaan (partisipasi) dari masyarakat, Dinas Kebudayaan dan Pariwisata melakukan beberapa pendekatan terhadap masyarakat dengan mengadakan program yang unik dan sangat menarik bagi masyarakat maupun wisatawan, antara lain dengan cara:

1) Pengadaan (pengoperasian) bus pariwisata gratis dengan cara pemungutan sampah plastik yang ada di sekitar objek wisata Pantai Padang sebagai pengganti tiket (ongkos) bus.

2) Dinas Kebudayaan dan Pariwisata Kota Padang mengajak masyarakat dan wisatawan untuk ikut berpartisipasi membersihkan pantai pada setiap hari Sabtu.

3) Dinas Kebudayaan dan Pariwisata Kota Padang menyediakan kebutuhan sarana dan prasarana di sekitar objek wisata Pantai Padang, meskipun sampai saat ini belum mampu mencukupi kebutuhan para pengunjung (wisatawan) secara maksimal. Disamping itu, Dinas Kebudayaan dan Pariwisata juga mempunyai 70 orang petugas kebersihan di kawasan Pantai Padang setengahnya adalah masyarakat sekitar Pantai Padang.

4) Menyebarkan brosur yang berisi ajakan dan seruan bersama-sama menjaga kelestarian lingkungan pantai.

Dengan beberapa upaya ini Dinas Kebudayaan dan Pariwisata Kota Padang akan dapat menjadikan Kota Padang sebagai destinasi Wisata Pesisir yang "nyaman dan berkesan indah".

\section{Penutup}

Berdasarkan hasil atau temuan penelitian dan pembahasan yang telah dikemukakan sebelumnya dapat ditarik beberapa kesimpulan antara lain sebagai berikut:

1. Partisipasi masyarakat dalam pelestarian lingkungan di kawasan Pantai Padang masih belum dapat dikatakan maksimal karena masih terdapat 
berbagai kekurangan dan kendala dalam penerapan partisipasi masyarakat tersebut. Meskipun demikian, program-program dari Dinas Kebudayaan dan Pariwisata Kota Padang dalam pelestarian lingkungan kawasan Pantai Padang setidaknya dapat membantu memotivasi masyarakat dalam pelestarian lingkungan di kawasan pantai ini. Salah satunya adalah dengan adanya program Bus Pariwisata gratis namun diganti pembayarannya dengan botol dan sampah plastik yang ada di kawasan Pantai Padang. Program ini dilaunching langsung oleh Walikota Padang. Program ini cukup memberi dampak positif dan kreatif bagi masyarakat guna mewujudkan Kota Padang yang bersih. Tidak hanya itu saja; Dinas Kebudayaan dan Pariwisata juga melakukan pendekatan kepada masyarakat dan wisatawan dengan mengajak masyarakat untuk ikut menjaga kelestarian lingkungan pantai yang dilakukan dengan menyebarkan brosur. Program yang dijalankan oleh Dinas Kebudayaan dan Pariwisata ini disambut baik oleh para wisatawan, dan masyarakat.

2. Ada beberapa faktor pendukung dan penghambat partisipasi masyarakat yang teridentifikasi dalam pelestarian lingkungan di kawasan Pantai Padang, antara lain:

a. Kota Padang, khususnya Pantai Padang, memiliki daya tarik dan keunikan tertentu sebagai daerah tujuan wisata. Keunikan dan daya tarik Kota Padang tentunya terletak pada keindahan alam dan budaya yang dimiliki, sehingga berpotensi menjadi daerah tujuan wisata. Yang menjadi faktor pendukung dalam hal ini adalah bahwa wisata alam masih cukup terjaga keasliannya serta wisata budayanya masih terjaga dengan baik dari sejak dahulu hingga sekarang.

b. Kawasan Pantai Padang ikut dikelola dan diperhatikan oleh Dinas Kebudayaan dan Pariwisata Kota Padang, sehingga hal ini ikut memotivasi masyarakat untuk ikut juga berpartisipasi .

c. Adanya partisipasi dari masyarakat dari luar kawasan pantai (wisatawan dan pedagang) untuk menjaga kelestarian lingkungan.

3. Selain faktor pendukung, ada pula beberapa faktor penghambat partisipasi masyarakat dalam pelestarian lingkungan kawasan Pantai Padang, antara lain:

a. Walaupun Pantai Padang memiliki keunikan daya tarik keindahannya, namun sarana dan prasarana pendukung untuk pelestarian lingkungan di kawasan ini masih kurang memadai, seperti kurangnya toilet umum dan bak sampah. Bak-bak sampai di kawasan ini selalu terlihat penuh dan tidak mampu menampung sampah secara maksimal; akhirnya membuat orang membuang sampah di dekat bak-bak sampah.

b. Program pelestarian lingkungan belum semuanya terealisasi secara merata dan belum berjalan dengan baik.

c. Kurangnya kesadaran masyarakat dan wisatawan terhadap sampah dan kelestarian lingkungan. 


\section{DAFTAR KEPUSTAKAAN}

A. Oktami Dewi, A. 2013. "Partisipasi Masyarakat Dalam Pengembangan Objek Wisata Bahari di Pulau Kapoposang Kabupaten Pangkajene dan Kepulauan”. Makasar: Universitas Hasanudin.

Isbandi Rukminto Adi. 2012. "Intervensi Komunitas dan Pengembangan Masyarakat sebagai Upaya Pemberdayaan Masyarakat sebagai Upaya Pemberdayaan Masyarakat".

Melis. 2016. “Analisis Partisipasi Masyarakat dalam Pembangunan Desa Di Desa Wawolesea Kecamatan Lasolo Kabupaten Konawe Utara". Kendari: Universitas Halu Oleo.

Pasaribu, I.L. dan Simajuntak. B. 1992. Sosiologi Pembangunan. Bandung: Tarsito.

Sastropoerto. R.A.S. 1998. Partisipasi Komunikasi, Persuasi dan Disiplin dalam Pembangunan. Bandung: PT. Alumni.

Supardi, I. 2003. Lingkungan Hidup dan Kelestariannya. Bandung: PT. Alumni.

Wira Prananta. 2014. "Faktor-faktor Yang Mempengaruhi Partisipasi Masyarakat dalam Pembangunan di Kelurahan Kemenangan Tani Kecamatan Medan Tuntungan. Medan: Universitas Sumatera Utara

Undang-Undang Nomor 23 Tahun 1997 tentang Pengelolaan Lingkungan Hidup.

Undang-Undang No 32 Tahun 2009 tentang Perlindungan dan Pengelolaan Lingkungan Hidup. 